\title{
Determining Factors of Corporate Governance in Women Corporative of East Java Indonesia
}

\author{
Eni Wuryani ${ }^{1, a}$, Merlyana Dwinda Yanthi ${ }^{1, b^{*}}$ \\ ${ }^{1}$ Accounting Department, Faculty of Economics, Universitas Negeri Surabaya \\ Jalan Ketintang, Surabaya 60231, Indonesia \\ e-mail: ${ }^{\mathrm{a}}$ eniwuryani@unesa.ac.id, ${ }^{\mathrm{b}}$ merlyanayanthi@unesa.ac.id \\ * Corresponding Author
}

\begin{abstract}
All over the world want organizations to be sustainable, like organizations in Indonesia. Corporate governance $(C G)$ implementation is a must in an organization. The application of corporate governance in Indonesia is applied to organizations in the form of cooperatives. The study aimed to determine factors of corporate governance in women corporative of East Java, Indonesia. Factors that include corporate governance are internal control, the rules for members, annual member meetings. The object of this study was 159 Cooperatives in East Java, Indonesia. The implementation of coporate governance in women's cooperatives has been going well, judging by the cooperative's performance appraisal. The implementation of internal control still needs to be improved. Cooperative members have mostly fulfilled their obligations as members through payment of basic contributions and mandatory contributions. The meeting held by members of most women's cooperatives was carried out on time. Cooperatives are microfinance institutions for cooperative members. Cooperatives are organizations that are established for the welfare of members. Implementation of corporate governance in women's cooperatives will improve cooperative performance.
\end{abstract}

Keywords: Corporate Governance, Internal Control, Performance, Women Cooperative, Microfinance

Article History: Received: April 272020 Revised: 1 October 2020 Accepted: October 92020

How to cite: Wuryani, E. \& Yanthi, M.D.(2020). Determining Factors of Corporate Governance in Women Corporative of East Java Indonesia. Akrual: Jurnal Akuntansi (JA), 11(2):136-148. DOI: https://doi.org/10.26740/jaj.v11n2.p136-145.

\section{INTRODUCTION}

Cooperative organizations have specific characteristics compared to other organizations. Cooperative organizations have the principle of corporate profits that can be enjoyed by all members of the cooperative. Divided benefits are taken from reports on the remaining results of the business. The component of the story on the remaining business results is the cooperative income of the business minus the operating expenses of the cooperative. The financial performance of the collective management will be accountable to members at the Annual Member Meeting. The Annual Budget Meeting will discuss the achievements of the previous year's performance and the collaborative business budget plan. Cooperatives are microfinance institutions, having an intermediary function as fund-channeling fund collectors. Cooperative as a function of collecting funds through the payment of principal savings members, mandatory savings, and voluntary savings. Collaborative as a function of 
channeling funds through giving credit to members. The financial management of cooperatives must be fair, transparent, and accountable. Organizations are microfinance institutions. Gietzen (2017) microfinance institutions face a low risk of liquidity. Microfinance institutions have the potential to maintain liquidity. Microfinance institutions can operate activities in paying off obligations in the short term.

According to Wuryani (2012), a cooperative is a legal entity carrying out cooperative activities based on democracy. According to Law on Indonesian Cooperative No. 17 issued in 2012, a union is a legal entity established by individuals or legal organization. A cooperative has economic, social, and cultural aspects according to its principles. The main goal of a cooperative is to prosper its members. The union has intermediary functions to collect and distribute funds. Members save their money as maximum savings, mandatory savings, and voluntary savings. The principal conservation is the initial money given by the member when registering. Later, the members are possibly to borrow the funds (loan) based on its terms and conditions. No collateral is needed when they apply for the loan. This is one of a cooperative's characteristics as it meets the principles of a cooperative, that is, by and for members.

Essential savings, mandatory savings, and voluntary savings will add assets to the cooperative. The assets owned by organizations are getting bigger, so the opportunity to get cooperative income is getting bigger. Cooperatives will get exciting income from members who borrow money from unions. Collective assets will be channeled to members through credit. Credit distribution to members raises accounts receivable. Cooperatives must manage the accounts receivable well to minimize uncollectible accounts. The cooperative organizational structure consists of collaborative management and cooperative members. The management consists of the Chairperson, Secretary, Treasurer, and Supervisor. Operational activities are contained in the Cooperative Business Budget Plan, which was approved at the Annual Member Meeting. The highest authority is in the members of the cooperative because the policy changes must get the approval of the members through the Annual Member Meeting. Personnel in the organizational structure must run according to their respective duties and functions. Implementation of corporate governance can be carried out if all staff in the organizational structure perform tasks and functions correctly. Cooperative management must have an attitude of justice, independence, transparency, and accountability. Collaborative management must be professional to improve performance. Shleifer and Vishny (1997) argue that proper organizational management can give trust to the owner about the return on investment invested. In the cooperative, the owner is a member of the collective. Returns on investment in the form of organizations in the way of remaining business results investment in cooperative members in the form of maximum savings, mandatory savings, and voluntary savings.

Xue \& Hong, (2016) Good corporate governance can reduce costs. The company will benefit from good corporate governance. Proper company management will limit management opportunism, especially in revenue. Briozzo et al. (2017) Corporate governance mechanisms in developing countries of small and medium enterprises (SMEs) are interesting to learn, especially from a gender perspective. The relationship between CG and gender, there is no relationship between women's participation at different levels: ownership, the board of directors, senior management, and auditing. It is also interesting to observe that capital concentration decreases because more people participate in ownership. 
Solovjova (2018) Establishment and development of financial centers contribute to economic growth. The establishment and development of commercial centers are influenced by several factors, such as geographical location, multicultural factors, tax and customs policies, immigration laws, competitive costs of financial services, economic, political and social factors. The development of commercial centers requires government support and balanced national policies aimed at increasing the competitiveness of business centers. Loukopoulos (2014) Strong resource potential is the power to earn income in the long run. Theriou (2015) Implementation of strategies using more financial information. The company also uses non-financial information in developing policies. Fetai (2015) Financial integration and commercial development have a positive effect on economic growth in developing countries and do not influence in developed countries.

Goel and Madan (2018) Not only do women entrepreneurs provide support to the economy, but they also play an important role in the organization to bring more innovation and involvement. Managerial and practical implications will help in designing policies for rapid financial inclusion. Financial inclusion plays an important role in women's entrepreneurship, and it is important to create more awareness, make the system easy, and create an enabling environment for women's entrepreneurship.

Ameer and Othman (2012) The company will improve its financial performance and maintain the business performance that is achieved well. The purpose of this study was to analyze the effect of cooperative governance on the financial performance of rural women's cooperatives in East Java, Indonesia. The policy of the East Java Governor since 2009 established the Women's Cooperative in each village, and there was one women's cooperative. Women's organizations have a purpose to prosper the village community. The Women's Cooperative was established to move the economy in the village through women's empowerment. Women's cooperatives as microfinance institutions have differences with banks. Women's cooperatives when giving loans to members do not need to use collateral. Cooperative governance proxied through internal control, cash flow, organization size, and implementation of member meetings.

Jensen and Meckling (1976) define agency relationships as contracts where one or more (principals) hire other people (agents) to do some services for their interests by delegating some decision-making authority to the agent. If both parties try to obtain maximum satisfaction, then there is a good reason to believe that the agent does not always act in the interests of the principal. Watts and Zimmerman (1990) implicitly recognize three forms of agency relations, namely owners and management, creditors with management, and government and management. The notion of principal is not only the owner of the company but also creditors and the government. In carrying out, the work principals need to delegate some decision-making authority to the agent.

Agency problems arise when managers have an obligation to maximize the welfare of shareholders, but on the other hand managers also have an interest in maximizing their health, so that in this case the agent is not in the benefits of optimizing the health of the owner, but has a tendency to pursue his interests at the expense of interests owner. This is usually done by the agent by providing information about the performance results that are not following the actual situation through the use of accounting numbers stated in the financial statements as the basis. ElKelish (2018) agency costs have a significant negative impact on corporate governance risks. The heterogeneous model of corporate governance 
is caused by a variety of different agency problems in various countries. There are several obstacles to achieving convergence in global corporate governance practices due to various agency problems throughout the country.

The association of agency theory with this study, the application of cooperative governance can reduce agency costs incurred by the company. Usman et al. (2018) the presence of women as directors will benefit from reducing agency costs by reducing the manager's opportunistic behavior and information asymmetry. Hesarzadeh and Bazrafshan (2018) The relationship between CEO ability and risk of regulatory review, negative and also statistically and economically significant for companies with low agent conflict levels and high levels of quality of corporate governance. The results of this study indicate that the relationship between CEO capability and regulatory review risk is positive and also statistically and economically significant for companies with high levels of agent conflict and low quality of corporate governance.

Most of the major corporate failures and financial scandals have resulted from agency problems due to director ineffectiveness (Tricker, 2012). Agency theory is a theory of corporate governance, effective board through directors to minimize agency problems. Corporate governance reforms, such as corporate governance codes, guidelines, and regulations, aim to increase board effectiveness (Ujunwa, 2012). In developed countries Most companies manage governance by providing insights on the board and financial performance. In developing countries there is still very little insight into the board and financial performance. Uhlaner et al. (2007), agency problems are minimal when management is largely in the hands of shareholders.

Srivastava et al. (2019) Research show a significant negative relationship between overall corporate governance and equity costs. Srivastava et al. (2018) there is a relationship between corporate governance and company performance. Good corporate governance will protect shareholder rights. Ntongho (2016) Economic considerations are not the only factor in influencing corporate governance regulations, because political and cultural elements are equally essential and culture has proven to be the primary mitigating factor towards convergence of corporate governance rules and principles. Mulcahy and Donnelly (2015) improved corporate governance significantly more in companies that have weak or extreme governance before losses occur.

Mussa et al. (2015) Corporate governance influences corporate financial decisions. Corporate governance correlates with the responsibility of total company debt. Corporate governance connects with responsibility for the number of dividends paid to shareholders. According to (Cornett et al., 2009) A suitable management mechanism in the company will support the company's performance. (Brown Caylor, 2006) Proper management in the company has a positive effect on company performance. Cornett et al. (2009) describe that corporate governance has a vital role in the production. Wuryani (2012) the application of organizational governance influences performance. Lys et al. (2015) Corporate accountability reporting is information to outsiders about the company's future financial prospects. Raj and Khana (2017) Governance performance was built in the last time period and studied additional changes in quality over a very long period.

Current and. Ariza, (2016) observable and unobservable institutional factors can influence compliance with Corporate Governance (CG), and some company-specific characteristics can influence CG ratings. Krechovska and Prochazkova, (2014) Good corporate governance and sustainable impact through a sustainable business management 
process. Toudas (2014) Corporate governance cannot improve performance. Companies must bear market risks. Investors are passive in monitoring and evaluating companies. Gupta and Mirchandani (2019) the results of his research on socially oriented Micro Finance Institutions (MFI) have greater customer reach with a higher percentage of female customers and lower average loan sizes compared to commercially oriented MFIs. Micro Finance Institutions (MFI) that is socially oriented has less cost per borrower and higher self-sufficiency in operations. Social oriented Micro Finance Institutions (MFI) (NGOs and Cooperatives/credit unions) show better social performance compared to commercially oriented MFIs. Afrifa and Tauringana (2015) Governance factors have a significant impact on performance.

Within the cooperative organizational structure, there must be a division of tasks and authority, so that each function can carry out the work correctly and be accountable for the job. Clear duties and powers will facilitate the evaluation or monitoring of responsibilities and authorities. Assessment and monitoring are internal control efforts. Umarovich (2017) Applied financial controls will be more efficient using information systems. Information systems as a means of control in organizations. Miguel (2017) Management accounting is a tool to achieve accountability and control in managing funding sources. Wuryani (2012) Internal control influences financial performance. Cooperatives carry out internal controls, including perspectives on cooperative activities, organizational and business supervision, supervision of financial capital. The implementation of internal controls will run well through the control environment, the application of competencies in cooperatives, the assignment of authority, responsibility, communication, and information. The control environment is the foundation for implementing internal controls. The control environment reflects all behavior, awareness of all elements in the cooperative

Azim et al. (2017) research on microfinance institutions on governance needs transparency. Research on microfinance institutions about an internal audit is high in minimizing corruption behavior. Suryanto (2016) information systems, company size, operating losses, and profits influence inspection. The examination has the effect of reducing fraudulent financial reporting systems. Michael and Goo (2015) Corporate governance in the areas of family ownership, concentration, self-dealing, executive compensation, and other issues. Excessive executive compensation, accounting, and audit weaknesses do not cause problems. ElKelish (2018) Corporate governance is influenced by internal and external factors.

Cooperative Law No. 17 of 2012 Cooperatives must report responsibly to members on the Annual Member Meeting Report. At the Annual Members' Meeting, the management says the activities of cooperative activities in the form of reports on remaining business results, statements of financial position, capital change reports and cash flow statements. At the annual membership meeting, the business budget plan will be approved for the following year. Members have an essential position in yearly member meetings. Members can provide input and assess the performance of cooperative management. Pang and Yuan (2018) The composition of the management and commitment of members can contribute to better performance. Atty et al. (2018) there is a significant relationship between CEO duality and company financial performance. This reflects the need to strengthen compliance with the Governance Code related to the duality status of the board of directors. There is a significant relationship between the size of the Board of 
Directors and the company's financial performance. This shows that larger council sizes are more effective in monitoring financial reporting. There is a significant relationship between Board of Directors meetings and company financial performance. This indicates that the Board of Directors' conference does not affect the company's performance. Usman et al. (2018), the presence of women as directors can provide benefits to shareholders. Hasan and Khalily (2019) Powerful Chief Executive Officer has a positive impact on the financial performance of Micro Finance Institutions (MFI). Gender diversity has a positive effect when balanced with gender diversity in management.

Cooperative Law No. 17 of 2012 cooperative members must pay basic contributions and mandatory contributions. The basic fee is paid at the beginning of the formation of the cooperative. Contributions must be paid every month. The amount paid on the principal contribution and the membership fee is based on the rules agreed by the member. More and more members will add to cooperative capital because more and more basic contributions and mandatory contributions are received.

\section{RESEARCH METHOD}

This research uses census data. The research samples are 159 cooperatives in East Java, Indonesia. One hundred fifty-nine organizations from East Java Indonesia Data analysis using with diskriptif.

The measurement of corporate governance uses a performance evaluation conducted by the Cooperative Office as a cooperative builder.

Assessment criteria:

1. a value of $85-100$ is very good

2. grades $80-84$ Good

3. a value of $70-79$ is quite

4. a value $<70$ less

Internal control measurements using audit assessments by the Cooperative Supervisor Measurement scale:

1. There is an inspection from the supervisor, and there are written and complete reports on the results of the examination, the value of 100

2. There is an examination from the supervisor, and there are reports on the results of the test in writing but not complete, a value of 75

3. There is an inspection from the supervisor, but the inspection report is combined with the Management's story, a value of 50

4. There is a check from the supervisor, but there are no written and complete reports on the results of the examination, the value of 25

5. There is no inspection by the supervisor, a value of 0

It measures the implementation of Annual Member Meetings for assessment when the Cooperative Management is responsible for operational activities for all members.

Measurement scale:

1. Conducted in January, a value of 100

2. Held in February, a value of 75

3. Held in March, a value of 50

4. Conducted from March to June, 25 points

5. Implemented above in July, a value of 0

Repayment of Principal Deposits from members and Mandatory Deposits of members 
Measurement: Amount of Principal Deposits and compulsory deposits paid compared to the number of Principal Deposits that should be paid.

Measurement Scale:

1. $100 \%$, value 100

2. $80 \%$ s/d $<100 \%$, value 75

3. $60 \% \mathrm{~s} / \mathrm{d}<80 \%$, value 50

4. $40 \%$ s/d $<60 \%$, value 25

5. < $40 \%$, value 0

\section{RESULTS AND DISCUSSION}

Table 1. Descriptive Statistics

\begin{tabular}{lrrrrr}
\hline & N & Minimum & Maximum & \multicolumn{1}{c}{ Mean } & $\begin{array}{c}\text { Std. } \\
\text { Deviation }\end{array}$ \\
\hline CG & 159 & 60,00 & 94,00 & 82,0126 & 10,65036 \\
Deposit & 159 & 100,00 & 100,00 & 100,0000 &, 00000 \\
IC & 159 & 25,00 & 100,00 & 53,1447 & 22,27953 \\
AMM & 159 & 25,00 & 100,00 & 77,3585 & 22,98742 \\
Valid N & 159 & & & & \\
(listwise) & & & & & \\
\hline
\end{tabular}

Table 2. Corporate Governance

\begin{tabular}{lcrr}
\hline Discription & Value & Amount & $\begin{array}{c}\text { Percentage } \\
(\%)\end{array}$ \\
\hline Very good & $85-100$ & 99 & 62,26 \\
Good & $80-84$ & 5 & 3,14 \\
Quite & $70-79$ & 32 & 20,13 \\
Less & $<70$ & 23 & 14,47 \\
Amount & & 159 & 100 \\
\hline
\end{tabular}


Table 3. Audit Assessments by The Cooperative Supervisor

\begin{tabular}{|c|c|c|c|}
\hline Description & Value & Amount & $\begin{array}{c}\text { Percentage } \\
(\%)\end{array}$ \\
\hline $\begin{array}{l}\text { There is an inspection from the supervisor, and there } \\
\text { are written and complete reports on the results of the } \\
\text { examination }\end{array}$ & 100 & 1 & 0,63 \\
\hline $\begin{array}{l}\text { There is an examination from the supervisor, and } \\
\text { there are reports on the results of the test in writing } \\
\text { but not complete }\end{array}$ & 75 & 72 & 45,28 \\
\hline $\begin{array}{l}\text { There is an inspection from the supervisor, but the } \\
\text { inspection report is combined with the Management's } \\
\text { story }\end{array}$ & 50 & 34 & 21,38 \\
\hline $\begin{array}{l}\text { There is a check from the supervisor, but there are no } \\
\text { written and complete reports on the results of the } \\
\text { examination }\end{array}$ & 25 & 52 & 32,70 \\
\hline There is no inspection by the supervisor & 0 & 0 & 0 \\
\hline Amount & & 159 & 100 \\
\hline
\end{tabular}

Table 4. Repayment of Principal Deposits from members and Mandatory Deposits of members

\begin{tabular}{cccc}
\hline Description & Value & Amount & Percentage (\%) \\
\hline Repayment 100\%, nilai 100 & 100 & 140 & 88 \\
Repayment $80 \%$ s/d < 100\% & 75 & 5 & 3 \\
Repayment $60 \%$ s/d < 80\% & 50 & 6 & 4 \\
Repayment $40 \%$ s/d < 60\% & 25 & 8 & 5 \\
Repayment $<40 \%$ & 0 & 0 & 0 \\
\hline Amount & & 159 & 100 \\
\hline
\end{tabular}

Women's cooperatives that received good ratings were $62.26 \%$, meaning that most women's cooperatives had implemented corporate governance. Cooperatives that get a good rating of $3.14 \%$. The cooperatives that get the assessment are quite $20.13 \%$. Cooperatives that get bad ratings by $14.47 \%$. The number of cooperatives that get appraisers is very good and good appraisals are greater than the assessment of sufficient and poor quality.

The cooperatives that supervise and carry out complete records are only $0.63 \%$. Internal control in women's cooperatives has been done but there are still many that have not been recorded as much as $45.28 \%$. This means it is necessary to improve internal control with the administration in terms of administration.

Cooperatives that conduct Annual Member Meetings on time in January are $45 \%$. Cooperatives that hold Annual Member Meetings on time in February by $21 \%$. Cooperatives that hold Annual Member Meetings on time in March are 32\%. Cooperatives that conduct Annual Member Meetings on time for assets from March to June are $2 \%$. 
Cooperatives that conduct Annual Member Meetings on time in July are 0\%. This shows that many cooperatives have carried out accountability functions to members.

$88 \%$ of cooperative members have paid the obligation to pay the principal savings and mandatory savings. Cooperative members of $12 \%$ who have not paid off the principal savings and mandatory savings. This shows the source of capital from members will be used for the benefit of members who need funds. Cooperatives have an intermediary function, namely the function of collecting funds and channeling funds in the form of giving credit to members.

The application of cooperative governance in organizations can be seen from the activeness of the chairman and members who support the operational accountability of the cooperative. Reporting of the chairman's responsibility is delivered at the annual member meeting. The responsibility of members is to carry out obligations as members and take an active role in cooperative operations. The cooperative business in this research is a savings and loan business. Cooperatives through Member Meetings determine the minimum loan value and the maximum loan value that can be given. Determination of the minimum loan value is related to the effectiveness of lending, while the decision of the maximum loan value is related to the emphasis on loan risk.

The results of this study support the stakeholder theory. Stakeholders will benefit from corporate governance implementation that improves performance. Cooperatives that perform well will help members and the surrounding community. Cooperative members can feel the results by obtaining business capital with low interest. The existence of cooperatives can reduce poverty and improve the economy of the community. This study supports Cornett, et al. (2009), Wuryani (2012) describes that corporate governance has a vital role in performance.

\section{CONCLUSION}

The implementation of corporate governance supports the principles of justice, independence, transparency, and accountability. Implementation of Cooperative management in cooperatives can be seen from the activeness of managers and members who support operational accountability of cooperatives. Internal control does not affect corporate governance, this means that in the implementation of cooperative operations, internal control has not gone well. Corporate governance can work well because rural communities lead to the value of honesty. The value of integrity and sense of ownership of cooperatives is very high so that the management in carrying out cooperative operations, based on applicable regulations. Corporate governance in women's cooperatives is mostly already good, as seen from the value of cooperative performance.

Many women cooperative members have fulfilled their obligations as members. obligations as members pay the basic contributions and mandatory contributions. Contributions must be paid every month. Women's cooperatives as savings and loan cooperatives have the task of raising funds and channeling and in the form of loans. The basic contributions and membership fees are paid by members to the cooperative as a form of raising funds. The greater the funds raised, the greater the funds that will be used to lend 
funds to members. Source of cooperative funds from membership fees. Women's cooperatives have not utilized loan funds from banks to increase capital.

Most of the annual women's cooperative member meetings are in accordance with the implementation guidelines. This shows the cooperative management has a high responsibility in managing the cooperative. Accountability for cooperative performance is conveyed during annual member meetings. Cooperative members have a high position in the cooperative, so the management needs to report the cooperative's performance to members. based on agency theory theory, members as owners and managers as agents. timely accountability indicates a high level of accountability for management.Management responsibilities are conveyed at annual member meetings. The burden of members to carry out obligations as members and take an active role in the operations of cooperatives. The more members participate, the more cooperative capital. Capital is allocated for lending activities to members. The organization has an excellent performance if it can do exercises to get income higher than the operating expenses. Reports on the remaining results of operations will increase with the active role of cooperative members. Business results report will be reported at the annual member meeting. In the meeting, the value distributed to the members will be decided, in the form of spreading the remaining proceeds of the business. Cooperative members feel the benefits of profit sharing. Other benefits of cooperative members, making money for companies do not need to use asset guarantees.

\section{REFRENCES}

Angelia, D., Suryaningsih, R. .2015. The Effect of Environmental Performance And Corporate Social Responsibility Disclosure Towards Financial Performance (Case Study to Manufacture, Infrastructure, And Service Companies That Listed At Indonesia Stock Exchange). Procedia - Social and Behavioral Sciences, 211(September), 348-355. https://doi.org/10.1016/j.sbspro.2015.11.045.

Afrifa Godfred Adjappong, Venancio Tauringana, 2015Corporate governance and performance of UK listed small and medium enterprises, Corporate Governance Vol. 15 NO. 5 2015, pp. 719-733.

Atty Ashraf Mohamed Abdel, Mohamed Moustafa soliman, Amr E. Youssef. 2018. The Effect of Board of Directors Characteristics on Firm's Financial Performance: An Empirical Study on the Most Active Firms in the Egyptian Stock Exchange, Open Access Library Journal 2018, Volume 5, e4993

Azim Mohammad I., Kuang Sheng, Meropy Barut, 2017, Combating corruption in a microfinance institution, Managerial Auditing Journal, Vol. 32 Issue: 4/5, pp.445462

Busyra Azheri, .2012. Corporate Social Responsibility; Dari Voluntary Menjadi Mandatory, Rajawali Pers, Jakarta.

Brown, Lawrence D. and Marcus L. Caylor. 2006. Corporate governance and firm valuation, Journal of Accounting and Public Policy, 25. pp. 409-434.

Briozzo, A., Albanese, D., \& Santol quido, D. 2017. Gobierno corporativo, financiamiento nero: un estudio de las pymes emisoras de tulos en los mercados de valores argentinos. Contaduria Y Administracion, 62(2), 358-376. 
https://doi.org/10.1016/j.cya.2017.03.002.

Cornett, Marcia Millon, Jamie John McNutt and Hassan Tehranian. 2009. Corporate governance and earnings management at large U.S. bank holding companies. Journal of Corporate Finance. Vol 15, pp. 412-430.

ElKelish Walaa Wahid, 2018, Corporate governance risk and the agency problem, International Journal of Business in Society, Vol. 18 Issue: 2, pp.254-269 International Journal of Business in Society, Vol. 18 Issue: 2, pp.254-269

Fetai, Besnik. 2015. Financial Integration and Financial Development: Does Financial Integration Matter? European Research Studies, Volume XVIII, Issue (2), pp. 97106.

Freeman. 1984. Strategic Management: A Stakeholders Approach, Fitman, Boston.

Gietzen, Thomas. 2017. The exposure of microfinance institutions to financial risk, Review of Development Finance xxx (2017), PP 1-14

Gupta Namrata, Anita Mirchandani. 2019. Corporate governance and performance of microfinance institutions: recent global evidences,

Goel Nidhi, Pankaj Madan, 2018, Benchmarking financial inclusion for women entrepreneurship - a study of Uttarakhand state of India, Benchmarking: An International Journal Vol. 26 No. 1, 2019 pp. 160-175.

Hesarzadeh Reza, Ameneh Bazrafshan, 2018. CEO ability and regulatory review risk, Managerial Auditing Journal, Vol. 34 Issue: 5, pp.575-605

Jensen, Michael C. and William H. Meckling. 1976. Theory of The Firm: Manajerial Behavior, Agency Cost and Ownership Structure. Journal of Financial Economics. Vol. 3, pp. 305-360.

Krechovska, M, P.T.Prochazkova. 2014. "Sustainability and its Integration into Corporate Governance Focusing on Corporate Performance Management and Reporting," Procedia Eng., vol. 69, pp. 1144-1151.

Kubíckova Dana, Irena Jindrichovska, 2016, Comparability and Reliability of Financial Information in the Sector of Czech SMES (ten years of IFRS as a part of Czech accounting context).

Lee, B. Brian., and B. Choi (2002), "Company Size, Auditor Type, and Earnings Management", Journal of Forensic Accounting (3), 27-50.

Liu, Qiao., and Zhou Joe Lu, (2007), "Corporate Governance and Earnings Management in the Chinese Listed Companies: A Tunneling Perspective",Journal of Corporate Finance 13, 881-906.

Loukopoulos George, and Theodoros Roupas. 2014. Financial Analysis of the Greek Private Health Sector over the Last Decade (2002-2012), European Research Studies, Volume XVII, Issue (2), pp. 3-19.

Michael Bryane, S.H. Goo, 2015, Corporate governance and its reform in Hong Kong: a study in comparative corporate governance. Corporate Governance, Vol. 1 Issue: 4

Miguel, N.P., J.C. Lage, J. I.De La Pea Esteban. 2017. A First Approach to a Public Financial Information System for Social Benefits, European Research Studies Journal Volume XX, Issue 2A, pp. 109-127.

Monti Nicolas Emanuel, Roberto Mariano Garcia. 2010. A Statistical Analysis to Predict Financial Distress, J. Service Science \& Management, 2010, 3, 309-335 
Mulcahy Mark, Ray Donnelly, 2015. Corporate governance, stickiness and losses, Corporate Governance, Vol. 15 Issue: 3, pp.391-408

Mussa, H, Z. Musová, and L. Debnárova. 2015. "Responsibility in The Corporate Governance Framework and Financial Decision Making Process," Procedia Econ. Financ., vol. 23, October, pp. 1023-1029.

Ntongho Rachael Ajomboh, 2016. Culture and corporate governance convergence, International Journal of Law and Management, Vol. 58 Issue: 5, pp.523-544

Pang Sulin, Jinmeng Yuan, A Study on Enterprise Risk Management and Business Performance. 2018. Journal of Financial Risk Management, 2018, 7, 123-138

Raj Alok, Rupika Khanna, 2017, Benchmarking performance of governance quality in Indian states using MCDM techniques, Benchmarking: An International Journal Vol. 25 No. 8, 2018 pp. 2850-2874

Shleifer, A. and R.W. Vishny. 1997. A Survey of Corporate Governance. Journal of Finance, Vol.52. pp.737-783.

Solovjova, I., R. R. Apoga, I Romanova. 2018. Competitiveness Enhancement of International Financial Centres European Research Studies Journal Volume XXI, Issue 1, PP 5 - 17.

Srivastava Varnita, Niladri Das, Jamini Kanta Pattanayak, 2018. Corporate governance: mapping the change, International Journal of Law and Management, Vol. 60 Issue: 1 , pp.19-33

Srivastava Varnita, Niladri Das, Jamini Kanta Pattanayak, 2019, Impact of corporate governance attributes on cost of equity: Evidence from an emerging economy, Managerial Auditing Journal, Vol. 34 Issue: 2, pp.142-161.

Suryanto, Tulus. 2016. Audit Delay and Its Implication for Fraudulent Financial Reporting: A Study of Companies Listed in the Indonesian Stock Exchange, European Research Studies Volume XIX, Issue 1, 2016 pp. 18 - 31.

Tanweer Hasan, · $\quad$ Shakil Quayes, Baqui Khalily, 2019, Role of governance on performance of microfinance institutions in Bangladesh, Eurasian Econ Rev (2019) 9:91-106 https://doi.org/10.1007/s40822-018-0102-8.

Teker, S., Teker, D., \& Güner, A. 2016. Financial Performance of Top 20 Airlines. Procedia - Social and Behavioral Sciences, 235(October), 603-610. https://doi.org/10.1016/j.sbspro.2016.11.035.

Theriou, Nikolaos G. 2015. Strategic Management Process and the Importance of Structured Formality, Financial and Non-Financial Information, European Research Studies, Volume XVIII, Issue (2), pp. 3-28

Toudas Kanellos, and Athanasios Bellas. 2014. Corporate Governance and its Effect on Firm Value and Stock Returns of Listed Companies on the Athens Stock Exchange, European Research Studies, Volume XVII, Issue (2), 2014 pp. 58-80.

Tricker, B. (2012), Corporate Governance: Principles, Policies and Practices, 2nd ed., Oxford University Press, Oxford.

Uhlaner, L., Wright, M. and Huse, M. (2007), "Private firms and corporate governance: an integrated economic and management perspective", Small Business Economics, Vol. 29 No. 3, pp. 225-241..

Ujunwa, A. (2012), "Board characteristics and the financial performance of Nigerian quoted firms", Corporate Governance: The International Journal of Business in Society, Vol. 12 No. 5, pp. 656-674. 
Umarovich A., U. Albekov, V. N. Gennadyevna, A. O. Vladimirovna, S. R. Alexandrovich. 2017. Block Chain and Financial Controlling in the System of Technological Provision of Large Corporations' Economic Security, European Research Studies Journal Volume XX, Issue 3B, pp. 3 - 12.

Usman Muhammad, Muhammad Umar Farooq, Junrui Zhang, Muhammad Abdul Majid Makki, Muhammad Kaleem Khan, 2018, Female directors and the cost of debt: does gender diversity in the boardroom matter to lenders? Managerial Auditing Journal, Vol. 34 Issue: 4, pp.374-392

Wuryani, Eni. 2012 The Improvement of the Women Cooperative Performance by Implementing Good Corporate Governance, IAMURE International Journal of Business and Management, Volume 3, pp 229 -240.

Xue, S., \& Hong, Y. 2016. Earnings management, corporate governance and expense stickiness. China Journal of Accounting Research, 9(1), 41-58. https://doi.org/10.1016/j.cjar.2015.02.001. 